\title{
"Translanguaging" and the implications for the future teaching of English in Norway
}

Jonas Yassin Iversen

Inland Norway University of Applied Sciences

jonas.iversen@inn.no

\begin{abstract}
This article explores the concept of translanguaging and its pedagogical implications.

Specifically, I discuss how pedagogical translanguaging can be implemented in the teaching of English in Norway in light of the revised English curriculum presented in November 2019. I examine how the new English curriculum requires English teachers to value multilingualism as a resource and include students' complete linguistic repertoire in their teaching of English. In 2018, researchers responded positively to the proposal for a revised English curriculum emphasising multilingualism, while teachers expressed that they did not understand the proposed competence aims involving students' linguistic backgrounds. Despite teachers' reservations, the final version presented in November 2019 continues to emphasise the inclusion of students' multilingual resources as part of the subject's "core elements" and competence aims. To address the issues raised by teachers, I explore how teachers can meet these requirements through pedagogical translanguaging. I present five facets of pedagogical translanguaging which can contribute to meet the requirements in the revised English curriculum: (1) raising students' awareness of multilingualism, (2) appreciating linguistic diversity and positioning students as competent multilinguals, (3) encouraging students to compare English with other languages in their linguistic repertoires, (4) using literature that includes translanguaging as a teaching resource and (5) implementing tasks that require students to draw on their complete linguistic repertoires.
\end{abstract}

Keywords: multilingual English teaching; English teaching in Norway; translanguaging; pedagogical translanguaging. 


\section{Introduction}

As Norwegian classrooms are becoming more linguistically diverse, English teaching should adapt to this reality. However, researchers examining multilingual English teaching in Norway have discovered that pre-service teachers are poorly prepared to teach English to multilingual students (Šurkalović, 2014), that in-service English teachers feel unprepared to teach multilingual students (Dahl \& Krulatz, 2016; Krulatz \& Torgersen, 2016) and that English teaching in multilingual classrooms is not differentiated based on students' language backgrounds (Burner \& Carlsen, 2019; Iversen, 2017). In this article, I make a case for pedagogical translanguaging as an approach to create inclusive classrooms for the $21^{\text {st }}$ century, where all students - regardless of linguistic background - can draw on a wider repertoire of their linguistic resources in their English language learning.

Over the past decade, the concept of translanguaging has become increasingly popular avenue for exploration in research on multilingualism and education. Much of its popularity among researchers and teachers alike might be due to its inclusive approach to language education, which may have transformative potential for schools and society (García \& Li Wei, 2014). However, translanguaging has not made a significant impact on the field of English and foreign language teaching in Norway, although this is changing (Beiler, 2019; Krulatz \& Iversen, 2019). In this article, I first elaborate on the meaning of translanguaging before presenting the concept of pedagogical translanguaging and discussing how multilingual students can deploy translanguaging strategies when learning English. Further, I review the revised English curriculum (Norwegian Directorate for Education and Training, 2019) and discuss how teachers can implement pedagogical translanguaging to meet the requirements in the proposed curriculum.

\section{Translanguaging}

Translanguaging can be defined as "the deployment of a speaker's full linguistic repertoire without regard for watchful adherence to the socially and politically defined boundaries of named (and usually national and state) languages" (Otheguy, García, \& Reid, 2015, p. 281). However, some researchers have criticised the concept for being inaccurate, as it is applied to describe different phenomena in classrooms and everyday interactions (Jaspers, 2018). In 
response to this criticism and to clarify my understanding of translanguaging, I present three fundamental assumptions underlying my application of the concept.

First, I understand language as a construct. Many researchers have challenged the traditional view of languages as separate entities and asserted that this view is closely connected to the development of the European nation states and nationalism (García, 2009). In fact, Otheguy, García and Reid (2015) claimed that:

languages are not true linguistic entities because their boundaries are established on nonlinguistic grounds. Rather, they are groupings of idiolects of people with shared social, political or ethnic identities that, once so grouped, are described using linguistic terms that tend to give the mistaken impression that the grouping was based on linguistic grounds in the first place. (p. 291)

This construction of different languages has progressed through a selective legitimation of the language varieties of powerful groups. As a consequence, the languages of less powerful groups have been deemed inappropriate and inadequate for academic purposes (Otheguy et al., 2015). Education systems have adopted this idea, particularly through the period of European nation building. Those in control of the educational system also control which languages are included in the classroom and whose children get to benefit from it (García, 2009, pp. 102-103).

The second assumption behind the concept of translanguaging is the understanding of language as an activity, performance or practice, rather than an object (Canagarajah, 2013; García \& Li Wei, 2014). Traditionally, researchers have defined languages separately from human beings and studied them as objects (García, 2009). According to Pennycook (2010):

To look at language as a practice is to view language as an activity rather than a structure, as something we do rather than a system we draw on, as a material part of social and cultural life rather than an abstract entity. (p. 2)

Rather than seeing language as a set of grammatical structures and forms, researchers on translanguaging view language as a means of communication. Based on this understanding, the focus in education should shift from language as a "code" to language as "function" (Baker \& Wright, 2017, p. 1).

Finally, an individual's communicative capacity is understood as a repertoire, rather than proficiency in various codes or named languages (García \& Li Wei, 2014). By "linguistic repertoire", I refer to all the communicative resources available to the speaker, including 
linguistic and other semiotic resources, such as clothes, artefacts or music (Pennycook, 2018, p.

12). Thus, everyone has a linguistic repertoire one can draw on in different communicative situations. Most students in Norwegian schools are familiar with several Norwegian dialects, understand other Scandinavian languages and develop literacy in two written standards of Norwegian (Bokmål and Nynorsk) as well as English. Furthermore, many students learn an additional language of prestige, such as French, German or Spanish. Hence, a person who seems to be a monolingual individual at a first glance might actually have a wide linguistic repertoire, even before one considers other semiotic resources the student may possess. According to García and Li Wei (2014), the linguistic repertoire is integral and not divided in discrete codes.

\section{Pedagogical translanguaging}

In educational contexts, translanguaging is not simply another strategy to deal with the "problem" of linguistic diversity. On the contrary, translanguaging is a way of understanding the concept of language, and it can be viewed as a new pedagogy (Creese \& Blackledge, 2015; García, Ibarra Johnson, \& Seltzer, 2017; García \& Li Wei, 2014). Extensive research has provided evidence for the advantages of pedagogical translanguaging and offered comprehensive examples of its application in various contexts (Cenoz \& Gorter, 2017; Creese \& Blackledge, 2010; Duarte, 2019; García \& Kleyn, 2016; Krulatz \& Iversen, 2019; Mazak \& Carroll, 2017; Paulsrud, Rosén, Boglárka, \& Wedin, 2017). In this section, I present some pedagogical implications of translanguaging.

Some researchers have argued that pedagogical translanguaging is primarily an attitude towards students' linguistic resources that is expressed through both deliberate and arbitrary actions aimed at developing the students' linguistic resources (Mazak, Mendoza, \& Mangonéz, 2017, p. 72). Contrary to this position, I argue that pedagogical translanguaging involves planned, structured and purposeful actions aimed at developing students' metalinguistic awareness, multilingual competence and identity; similarly, other researchers have stressed the importance of a deliberate effort to draw on students' full linguistic repertoires (Ganuza \& Hedman, 2017; García et al., 2017; Toth \& Paulsrud, 2017). In other words, one cannot speak of pedagogical translanguaging as occurring in all contexts where more than one language is deployed for teaching and learning. Rather, the use of the different languages must have a purpose and structure. Without a structured and planned translanguaging, the dominant language 
of education and society will not provide sufficient space for minoritised languages, and they will eventually be replaced by the dominant language (Cenoz \& Gorter, 2017).

With increasing globalisation, all students must be prepared for the linguistic diversity they will encounter in the future. It is no longer enough to be proficient in only one language; indeed, the future will require a multilingual competence of everyone (García, 2009). Thus, pedagogical translanguaging benefits not only students from multilingual homes, but also those from monolingual homes (García, 2009). Yet, pedagogical translanguaging will most likely have the greatest impact on students whose home language differs from the language of instruction. As Conteh (2018) noted, this is:

the central tension of language policy and pedagogy in superdiverse contexts - the need to understand the value of maintaining and even strengthening the diverse repertoires of multilingual students at the same time as ensuring that they become competent and successful mediators of the discourses of power in the contexts in which they live their lives. That the two are mutually supportive is perhaps the most important piece of professional knowledge that mainstream teachers need. (p. 484)

Translanguaging as pedagogy aims at solving this tension by developing students' proficiency in all of the languages they know. Since language boundaries are constructed, language instruction should not be limited to separate languages. Rather, teachers should develop students' metalinguistic awareness and encourage them to draw on their entire linguistic repertoires. Students should be positioned as capable multilingual individuals with the ability to use all of their linguistic resources in the learning process (Palmer, Martínez, Mateus, \& Henderson, 2014).

Pedagogical translanguaging provides multiple advantages, particularly for students with a home language that is different from the language of instruction. Baker and Wright (2017) presented four clear advantages of translanguaging. First, translanguaging may promote a deeper and fuller understanding of the subject matter. Second, it might help students develop oral communication and literacy skills in their weaker language. Third, it can potentially strengthen the bonds between school and home. Fourth, translanguaging may help multilingual students with limited proficiency in the language of instruction integrate with proficient speakers of this language (Baker \& Wright, 2017, pp. 281-282). Paulsrud, Rosén, Straszer and Wedin (2017) argued that "translanguaging as a pedagogy indicates that all students' whole linguistic 
repertoires are invited, included, recognized and accepted in the learning act beyond divisions into multilingual and monolingual students" (p. 16). Hence, translanguaging has a transformative potential in that it can challenge linguistic hierarchies and empower students belonging to linguistic minorities (Creese \& Blackledge, 2010; García, 2009; Mazak \& Carroll, 2017). Moreover, multilingual approaches to education help students "to become global and responsible citizens as they learn to function across cultures and worlds, that is beyond the cultural borders in which traditional schooling often operates" (García, 2009, p. 6).

\section{Translanguaging for support, expansion and enhancement}

Depending on students' language proficiencies, teachers can use translanguaging in the classroom for different purposes (García \& Kano, 2014; García \& Li Wei, 2014). In this section, I describe three ways for students to use translanguaging as a learning strategy, first presented by García and Kano (2014).

Students with limited proficiency in the language of instruction tend to use translanguaging as a support when they try to make sense of a text or a lesson. Drawing on a language in which they already have advanced proficiency can help them understand the content of the teacher's instruction or a text they read. In a study of multilingual students in English classrooms in Norway, Iversen (2017) described how students with limited proficiency in Norwegian drew on their home language through translation and explanations from parents or peers to make sense of the English content.

Multilingual students can also use translanguaging to expand their knowledge. These students draw on their complete linguistic repertoires to gain a more comprehensive understanding of the content. García and Kano (2014, p. 269) described how a student writing in English would insert Japanese words whenever she could not remember the English equivalents on the spot. Researchers (García \& Kano, 2014; García \& Li Wei, 2014) have referred to these processes of translanguaging for support and expansion as dependent translanguaging. Teachers can play a decisive role in training multilingual students to translanguage for support and expansion in the English classroom.

In contrast to dependent translanguaging, "independent translanguaging" includes translanguaging practices where students translanguage to enhance their comprehension (García \& Kano, 2014). Experienced multilinguals manage to put their complete linguistic repertoires to 
use in different circumstances to make meaning and express themselves appropriately. The different parts of their repertoires enable students to access information in multiple languages and develop metalinguistic awareness. For example, Canagarajah (2011) described how one student applied translanguaging as a literary device and used it to represent her identity and voice through her writing.

So far, I have presented some key ideas behind the concept of translanguaging, the pedagogical implications of this concept and three practical approaches to translanguaging in the classroom. In the following section, I review the new English curriculum (Norwegian Directorate for Education and Training, 2019) and consider how the revised curriculum encourages translanguaging in the English classroom.

\section{Translanguaging and the new English curriculum}

The revised national curriculum is a result of the Official Norwegian Report 2015:8, presented by the Ludvigsen Committee (Norwegian: Ludvigsen-utvalget). After asserting that cultural diversity and multilingualism should be recognised as resources for Norwegian society (Ludvigsen et al., 2015, p. 19), the committee proposed that communication, cooperation and participation should be key competences in the school of the future (Ludvigsen et al., 2015, p. 27). To achieve this goal, the committee argued for closer links between the different language curricula (e.g. Norwegian, English and foreign languages) within Norwegian education (Ludvigsen et al., 2015, p. 45).

This approach of viewing linguistic or communicative competences as an integral repertoire rather than separate competences in distinctive codes is in line with the translanguaging literature presented above. It is therefore encouraging to note that the committee's suggestions seem to have influenced the recent process of curriculum revisions within Norwegian education. The new English curriculum aims to prepare students for a culturally and linguistically diverse society. The introduction to this proposal states:

English is a central subject for cultural understanding, communication, education, and identity development. The subject shall provide students with the ability to communicate with others locally and globally, regardless of cultural and linguistic background. English shall contribute to develop students' intercultural understanding of different ways of life, 
ways of thinking, and communication patterns. (Norwegian Directorate for Education and Training, 2019) ${ }^{1}$

This paragraph reveals that the revised curriculum considers English to be a subject that opens up Norwegian classrooms to the world, has an international perspective and can invite conversations about linguistic and cultural diversity related to students' daily life in Norway. This understanding aligns with the Ludvigsen Committee's acknowledgement of the cultural and linguistic diversity in Norway and the assumption that Norway will become increasingly globalised in the years to come (Ludvigsen et al., 2015, p. 10). Moreover, the introduction explicitly states that "the students shall experience that the ability to speak several languages is a resource in school and society" (Norwegian Directorate for Education and Training, 2019).

This awareness of linguistic diversity has implications for how the curriculum deals with language learning and the subsequent competence aims. Drawing on the committee's assessment of multilingualism as a resource (Ludvigsen et al., 2015, p. 19), the new curriculum invites the inclusion of students' home languages into the teaching of English. In the so-called "core elements" of the revised curriculum, the Norwegian Directorate for Education and Training establishes that "language learning involves seeing connections between English and other languages the student knows" (2019). This competence is also included as one of the key competence aims repeated after years 4, 7, 10 and 11. Specifically, after year 4, students are expected to "discover and play with words and expressions shared by English and other languages the student knows" (Norwegian Directorate for Education and Training, 2019). After year 7, students should be able to explore and discuss some linguistic similarities and differences between English and other languages the students know. Moreover, after year 10, the student is expected to explore and describe similarities and differences between English and other languages the student knows. Finally, after year 11, students should apply their knowledge about the connections between English and other languages the student knows (Norwegian Directorate for Education and Training, 2019). Consequently, these competence aims obligate English teachers to include multilingual students' complete linguistic repertoires in their teaching. Furthermore, they require that English teachers consider multilingualism as a resource in the process of learning English and require students to capitalise on this resource.

\footnotetext{
${ }^{1}$ I translated all quotes from the Norwegian Directorate for Education and Training from Norwegian to English.
} 
According to the revised curriculum, language teaching should also aim to provide students with "choice and opportunities in communication and interaction" (Norwegian Directorate for Education and Training, 2019) in accordance with the Ludvigsen Committee's emphasis on competences, such as communication, cooperation and participation (Ludvigsen et al., 2015, p. 27). Furthermore, the revised curriculum states that students are expected to develop an ability to see their own and others' identities in a multilingual and multicultural context (Norwegian Directorate for Education and Training, 2019).

Despite the new curriculum's emphasis on multilingualism, the original proposal for a revised English curriculum, presented in October 2018, also established an expectation that students be able to "capitalise on multilingualism as a resource" after years 4, 7, 10 and year 11 (Norwegian Directorate for Education and Training, 2018b). Further, the curriculum invited students to "experiment with words and expressions shared by English and other languages the student knows", which could be considered an invitation for teachers and students alike to engage in translanguaging practices. In 2018, several universities expressed an appreciation for the focus on multilingualism in the proposed curriculum (Norwegian Directorate for Education and Training, 2018a). Yet, some teachers and schools responded that they did not understand the competence aims involving students' linguistic backgrounds or know what to do with them (Norwegian Directorate for Education and Training, 2018a). This feedback confirmed a gap between what researchers have described about language learning for multilingual individuals and what teachers in schools know about the topic (Dahl \& Krulatz, 2016; Krulatz \& Torgersen, 2016). The teachers' feedback seems to have influenced the final version of the curriculum to a certain degree as evidenced by the removal of the requirements to "capitalise on multilingualism as a resource" and "experiment with words and expressions shared by English and other languages the student knows" (cf. Norwegian Directorate for Education and Training, 2018b).

Despite these revisions, the new English curriculum aims to prepare students for a culturally and linguistically complex society. Moreover, it requires English teachers to value multilingualism as a resource in the classroom and provide all students with an opportunity to capitalise on their complete linguistic repertoires. Furthermore, the proposed curriculum aims to enable students to communicate in various situations and provide them with choice and opportunities in communication. These ambitions are all in accordance with a translanguaging 
understanding of language. Thus, in the next section, I describe how pedagogical translanguaging can be one approach to meet the requirements in the revised curriculum.

\section{Implications for the teaching of English}

Pedagogical translanguaging can be implemented only in a classroom where linguistic diversity is truly celebrated and supported. Unless students feel that all of their languages are acknowledged and valued, they will likely hide parts of their linguistic repertoires from their teachers (Cummins, 2000). Based on the research literature on pedagogical translanguaging (e.g. García et al., 2017; García \& Kleyn, 2016) and the revised English curriculum, in this section, I propose five facets of pedagogical translanguaging in the English classroom.

The first facet involves increasing students' awareness of the linguistic diversity that surrounds them every day. A popular activity to increase students' awareness of their own and their peers' multilingualism is to create language portraits (Busch, 2012). In this exercise, students receive a silhouette symbolising themselves, and they are invited to fill the silhouette with different colours. Each colour indicates one language, and the placement of the colour signals for what purpose the language is used. This activity allows students to have a discussion about multilingualism and linguistic diversity. Furthermore, the teacher can include studies of the linguistic situation in former British colonies, such as in Tanzania, India and Singapore, to provide students with an understanding of the complexity of linguistic diversity around the world

The second facet is to express appreciation for linguistic diversity. Many students with a migrant background might be hesitant to draw upon their home language because they have previously experienced the exclusion of these languages from school (Iversen, 2017). Thus, for multilingual students to be able to capitalise on their multilingualism, they must be positioned as competent, and they must see their full linguistic repertoires as resources (Palmer et al., 2014). If schools position students as competent and practice a language policy where they are encouraged to use their full linguistic repertoires in the school context, students' self-esteem will increase (Sierens \& Van Avermaet, 2014). Conversely, students might be positioned as disadvantaged and incompetent in the language of instruction if they feel that their home languages are not valued and appreciated in the school context. When the teacher explicitly acknowledges students' full linguistic repertoires, describes students as competent and points out students' 
multilingual competence, students might feel safe to draw on greater parts of their linguistic repertoires (García \& Li Wei, 2014).

The third facet concerns teachers' encouragement of students to compare vocabulary and grammatical features in English with other languages the students know besides the official language of the school (Duarte, 2019, p. 9). For some students, the constant comparison between English and Norwegian is not sufficient to support their learning of English (e.g. Iversen, 2017). To support English learners, the teacher should explicitly encourage students to translate key vocabulary into, and compare grammar with, other languages in the students' repertoires. If the teacher wants to create an inclusive classroom environment that celebrates multilingualism, they should also invite students to explain differences between English, Norwegian and other languages in their repertoires. This activity meets the requirement in the new English curriculum to "see connections between English and other languages the student knows" (Norwegian Directorate for Education and Training, 2019). Furthermore, such practices function as a support for students with limited proficiency in Norwegian and/or English and as an expansion or enhancement for more proficient speakers of these languages.

The fourth facet of pedagogical translanguaging includes the introduction of literature with translanguaging features (Ebe \& Chapman-Santiago, 2016; García, 2009, p. 362). For example, much Chicano literature draws on both English and Spanish and can be excellent starting points to discuss cultural and linguistic diversity in the United States. Furthermore, literature originating in the Somali and Afghan diaspora, such as novels by Nadifa Mohamed and Khaled Hosseini, include translanguaging features and are appropriate for more advanced learners. This sort of literature aligns with the proposed English curriculum's ambition to provide "students with the ability to communicate with others locally and globally, regardless of cultural and linguistic background" (Norwegian Directorate for Education and Training, 2019). Students should therefore have the opportunity to work with literature that draws on multiple linguistic resources like the communication they will encounter in an increasingly globalised world. Furthermore, the revised curriculum states that "English shall contribute to develop students' intercultural understanding of different ways of life, ways of thinking, and communication patterns" (Norwegian Directorate for Education and Training, 2019). Diasporic literature can be an appropriate way to meet this competence aim.

Finally, the teacher should create concrete assignments that draw on students' full 
linguistic repertoires (García, 2009, p. 362). For example, the English teacher can facilitate multilingual writing assignments that require students to do parts of the writing in a language other than English (e.g. Krulatz \& Iversen, 2019). Less proficient students could draw on their home language as a support in the process of writing, while more proficient students could draw on greater parts of their repertoires to expand or enhance their metalinguistic awareness (Beiler, 2019; García \& Kano, 2014). Another approach is to invite students to write an analysis in English of poetry or other texts written in their home language. Such an assignment could be done in the English subject alone or as a cross-curricular assignment. This approach could help students to notice connections between English and other languages in their repertoires (e.g. Norwegian Directorate for Education and Training, 2019). Such approaches do not contradict an intention to prepare students for written exams, where they are required to write coherent texts in English. Translanguaging can be included both in the process of developing written proficiency in English and as a literary device in students' written exams. With the revised curriculum, assessment criteria should also open up for creative writing that strategically includes elements from languages beyond English.

Some teachers might question the feasibility of implementing a translanguaging pedagogy in their classroom unless they are proficient speakers of their students' home languages. Indeed, much research on translanguaging has investigated classrooms where the teacher was proficient in the home language of the students and where only two languages were present. Whether the studies were conducted in English-Spanish bilingual classrooms in the United States (García \& Velasco, 2014), in Welsh-English classrooms in Wales (Lewis, Jones, \& Baker, 2012) or in Swedish-English and Swedish-Finnish bilingual classrooms in Sweden (Straszer, 2017; Toth \& Paulsrud, 2017), they have all focused on the use of only two languages in the classroom. The situation may differ in Norway, where students often have much more diverse backgrounds.

However, an increasing number of studies have demonstrated how translanguaging can be applied in even more diverse classroom contexts (Goodman, 2017; Makalela, 2017; Mary \& Young, 2017; Rosiers, 2017). These studies have shown that all teachers can express appreciation of the linguistic diversity in the classroom, regardless of their own proficiency in the languages. Studies have also illustrated how teachers can translate key words and concepts using online dictionaries or ask the students to translate these terms to promote learning (García 
\& Li Wei, 2014; Mary \& Young, 2017). Krulatz and Iversen (2019) showed how a teacher can carry out multilingual writing assignments without any proficiency in the students' home languages. Furthermore, teachers can create a learner-centred classroom that encourages students to collaborate with other students who share a home language and support each other using the common home language (Rosiers, 2017). Teachers can also act as co-learners, exploring the students' home languages by positioning their students as experts in their respective languages. In other words, multiple strategies exist for enacting a translanguaging pedagogy in the classroom for teachers who are not proficient speakers of their students' home languages.

Other teachers might emphasise that their main concern is to teach English, regardless of their students' linguistic background. While an English teacher's responsibility is to teach English, all students, including multilingual students, are entitled to differentiated instruction. Hence, the teacher's obligation is both to teach English and to create translanguaging spaces where "children are given agency to act linguistically by being both creative and critical, and where teachers encourage those actions" (García \& Li Wei, 2014, p. 74). Giving students agency to learn through multiple languages will promote learning. Consequently, an important part of translanguaging as pedagogy is to contribute to the establishment of such translanguaging spaces in the classrooms.

In conclusion, English teachers who would like to implement pedagogical translanguaging to meet the requirements in the new English curriculum can consider five pedagogical solutions. They can facilitate translanguaging by raising students' awareness about multilingualism. Then, they can express appreciation of linguistic diversity by acknowledging the advantages associated with multilingualism and position students as competent language users. Teachers can also introduce texts that include examples of translanguaging and encourage students to draw on their full linguistic repertoires through translation and comparison. Finally, they can create assignments that require students to capitalise on their full linguistic repertoires.

\section{Concluding remarks}

In this article, I have highlighted how the revised English curriculum requires that English teachers include a wider repertoire of multilingual students' linguistic resources in their classrooms (Norwegian Directorate for Education and Training, 2019). Although teachers and schools expressed uncertainty about the meaning of the competence aims related to 
multilingualism and how they could be met when the proposal was introduced in October 2018, the requirement to include students' multilingualism has remained in the final version presented in November 2019 (Norwegian Directorate for Education and Training, 2019). The mixed response to the first proposal indicates a discrepancy between what research has revealed about multilingualism and language learning and what in-service teachers know about the topic (Dahl \& Krulatz, 2016; Krulatz \& Torgersen, 2016). In response, I have described certain facets of pedagogical translanguaging and suggested how these approaches can be implemented in instruction of English in Norway to meet the requirements in the revised English curriculum and to support multilingual learners of English.

\section{References}

Baker, C., \& Wright, W. E. (2017). Foundations of bilingual education and bilingualism (6th ed.). Bristol, UK: Multilingual Matters.

Beiler, I. R. (2019). Negotiating multilingual resources in English writing instruction for recent immigrants to Norway. TESOL Quarterly. doi:10.1002/tesq.535

Burner, T., \& Carlsen, C. (2019). Teacher qualifications, perceptions and practices concerning multilingualism at a school for newly arrived students in Norway. International Journal of Multilingualism. doi:10.1080/14790718.2019.1631317

Busch, B. (2012). The linguistic repertoire revisited. Applied Linguistics, 33(5), 503-523. doi:10.1093/applin/ams056

Canagarajah, S. (2011). Codemeshing in academic writing: Identifying teachable strategies of translanguaging. Modern Language Journal, 95(17).

Canagarajah, S. (2013). Literacy as translingual practice: Between communities and classrooms. New York, NY: Routledge.

Cenoz, J., \& Gorter, D. (2017). Minority languages and sustainable translanguaging: Threat or opportunity? Journal of Multilingual and Multicultural Development, 38(10), 901-912. doi:10.1080/01434632.2017.1284855

Conteh, J. (2018). Translanguaging as pedagogy - A critical review. In A. Creese \& A. Blackledge (Eds.), The Routledge handbook of language and superdiversity (pp. 473-487). London, UK: Routledge.

Creese, A., \& Blackledge, A. (2010). Translanguaging in the bilingual classroom: A pedagogy for learning and teaching? The Modern Language Journal, 94(1), 103-115. doi:0026$7902 / 10 / 103-115$

Creese, A., \& Blackledge, A. (2015). Translanguaging and identity in educational settings. Annual Review of Applied Linguistics, 35, 20-35. doi:10.1017/S0267190514000233

Cummins, J. (2000). Language, power and pedagogy. Bristol, UK: Multilingual Matters.

Dahl, A., \& Krulatz, A. (2016). Engelsk som tredjespråk: Har lærere kompetanse til å støtte flerspråklighet? [English as a third language: Do teachers have competence to support multilingualism?]. Acta Didactica Norge, 10(1), 1-18. doi:10.5617/adno.2397

Duarte, J. (2019). Translanguaging in the context of mainstream multilingual education. International Journal of Multilingualism. doi:10.1080/14790718.2018.1512607 
Ebe, A. E., \& Chapman-Santiago, C. (2016). Student voices shining through: Exploring translanguaging as a literary device. In O. García \& T. Kleyn (Eds.), Translanguaging with multilingual students: Learning from classroom moments (pp. 57-82). New York, NY: Routledge.

Ganuza, N., \& Hedman, C. (2017). Ideology versus practice: Is there a space for pedagogical translanguaging in mother tongue instruction? In B. Paulsrud, J. Rosén, B. Straszer, \& $\AA$. Wedin (Eds.), New perspectives on translanguaging and education (pp. 208-225). Bristol, UK: Multilingual Matters.

García, O. (2009). Bilingual education in the 21st century: A global perspective. Malden, MA: Wiley-Blackwell.

García, O., Ibarra Johnson, S., \& Seltzer, K. (2017). The translanguaging classroom: Leveraging student bilingualism for learning. Philadelphia, PA: Caslon.

García, O., \& Kano, N. (2014). Translanguaging as process and pedagogy: Developing the English writing of Japanese students in the US. In J. Conteh \& G. Meier (Eds.), The Multilingual turn in languages education (pp. 258-277). Bristol, UK: Multilingual Matters.

García, O., \& Kleyn, T. (Eds.). (2016). Translanguaging with multilingual students: Learning from classroom moments. New York, NY: Routledge.

García, O., \& Li Wei. (2014). Translanguaging: Language, bilingualism and education. New York, NY: Palgrave Macmillan.

García, O., \& Velasco, P. (2014). Translanguaging and the writing of bilingual learners. Bilingual Research Journal, 37(1), 6-23. doi:10.1080/15235882.2014.893270

Goodman, B. A. (2017). The ecology of language and translanguaging in a Ukrainian university. In C. M. Mazak \& K. S. Carroll (Eds.), Translanguaging in higher education. Beyond monolingual ideologies (pp. 50-69). Bristol, UK: Multilingual Matters.

Iversen, J. (2017). The role of minority students' L1 when learning English. Nordic Journal of Modern Language Methodology, 5(1), 35-47.

Jaspers, J. (2018). The transformative limits of translanguaging. Language \& Communication, 58, 1-10. doi:10.1016/j.langcom.2017.12.001

Krulatz, A., \& Iversen, J. (2019). Building inclusive language classroom spaces through multilingual writing practices for newly-arrived students in Norway. Scandinavian Journal of Educational Research. doi:10.1080/00313831.2018.1557741

Krulatz, A., \& Torgersen, E. N. (2016). The role of the EFL classroom in maintaining multilingual identities: Issues and considerations in Sør-Trøndelag public schools. In E. Amanti, J. Álvarez Valencia, \& E. Mackinney (Eds.), Critical views on teaching and learning English around the globe (pp. 53-68). Charlotte, NC: Information Age Publishing.

Lewis, G., Jones, B., \& Baker, C. (2012). Translanguaging: Developing its conceptualisation and contextualisation. Educational Research and Evaluation, 18(7), 641-670. doi:10.1080/13803611.2012.718490

Ludvigsen, S., Gundersen, E., Kleven, K., Rege, M., Øye, H., Indregard, S., . . . Sundberg, D. (2015). NOU 2015:8. Fremtidens skole: Fornyelse av fag og kompetanser [Norwegian Official Report (2015:8): The school of the future: Renewal of subjects and competences]. Oslo, Norway: Ministry of Education and Research. Retrieved from https://www.regjeringen.no/no/dokumenter/nou-2015-8/id2417001/sec1 
Makalela, L. (2017). Translanguaging practices in a South African institution of higher learning: A case of Ubuntu multilingual return. In C. M. Mazak \& K. S. Carroll (Eds.),

Translanguaging in higher education: Beyond multilingual ideologies (pp. 11-28). Bristol, UK: Multilingual Matters.

Mary, L., \& Young, A. S. (2017). From silencing to translanguaging: Turning the tide to support emergent bilinguals in transition from home to pre-school. In B. Paulsrud, J. Rosén, B. Straszer, \& $\AA$. Wedin (Eds.), New perspectives on translanguaging and education (pp. 108-128). Bristol, UK: Multilingual Matters.

Mazak, C. M., \& Carroll, K. S. (Eds.). (2017). Translanguaging in higher education: Beyond monolingual ideologies (Vol. 104). Bristol, UK: Multilingual Matters.

Mazak, C. M., Mendoza, F., \& Mangonéz, L. P. (2017). Professors translanguaging in practice: Three cases from a bilingual university. In C. M. Mazak \& K. S. Carroll (Eds.), Translanguaging in higher education: Beyond monolingual ideologies (pp. 70-90). Bristol, UK: Multilingual Matters.

Norwegian Directorate for Education and Training. (2018a). Engelsk - oppsummering av innspill [English - Summary of feedback]. Retrieved from https://www.udir.no/laring-ogtrivsel/lareplanverket/fagfornyelsen/oppsummeringer-av-7000-innspill-tillareplanskissene/engelsk-fellesfag--oppsummering-av-innspill/

Norwegian Directorate for Education and Training. (2018b). Læreplan i engelsk [English curriculum]. Retrieved from https://hoering.udir.no/Hoering/v2/271?notatId=512

Norwegian Directorate for Education and Training. (2019). Læreplan i engelsk [National curriculum for English]. Oslo, Norway: Norwegian Directorate for Education and Training. Retrieved from https://www.udir.no/lk20/eng01-04

Otheguy, R., García, O., \& Reid, W. (2015). Clarifying translanguaging and deconstructing named languages: A perspective from linguistics. Applied Linguistics Review, 6(3), 281307. doi:10.1515/applirev-2015-0014

Palmer, D. K., Martínez, R. A., Mateus, S. G., \& Henderson, K. (2014). Reframing the debate on language separation: Towards a vision for translanguaging pedagogies in dual language classrooms. The Modern Language Journal, 98(3), 758-772. doi:10.1111/j.15404781.2014.12121.x

Paulsrud, B., Rosén, J., Boglárka, S., \& Wedin, A. (Eds.). (2017). New perspectives on translanguaging and education. Bristol, UK: Multilingual Matters.

Paulsrud, B., Rosén, J., Straszer, B., \& Wedin, Å. (2017). Perspectives on translanguaging in education. In B. Paulsrud, J. Rosén, B. Straszer, \& Å. Wedin (Eds.), New perspectives on translanguaging and education (pp. 10-19). Bristol, UK: Multilingual Matters.

Pennycook, A. (2010). Language as a local practice. London, UK: Routledge.

Pennycook, A. (2018). Repertoires, registers and linguistic diversity. In A. Creese \& A. Blackledge (Eds.), The Routledge handbook of language and superdiversity (pp. 3-15). London, UK: Routledge.

Rosiers, K. (2017). Unravelling translanguaging: The potential of translanguaging as a scaffold among teachers and pupils in superdiverse classrooms in Flemish education. In B. Paulsrud, J. Rosén, B. Straszer, \& A. Wedin (Eds.), New perspectives on translanguaging and education (pp. 148-169). Bristol, UK: Multilingual Matters.

Sierens, S., \& Van Avermaet, P. (2014). Language diversity in education: Evolving from multilingual education to functional multilingual learning. In D. Little, C. Leung, \& P. Van 


\section{Nordic Journal of Modern Language Methodology}

2019, 7 (1), 50-66 Peer reviewed

Avermaet (Eds.), Managing diversity in education (pp. 204-222). Bristol, UK: Multilingual Matters.

Straszer, B. (2017). Translanguaging space and spaces for translanguaging: A case study of a Finnish-language pre-school in Sweden. In B. Paulsrud, J. Rosén, B. Straszer, \& Å. Wedin (Eds.), New perspectives on translanguaging and education (pp. 129-147). Bristol, UK: Multilingual Matters.

Šurkalović, D. (2014). Forbereder grunnskolelærerutdanningen engelsklærere for undervisning i engelsk som tredjespråk i Norge? [Does the general teacher education prepare English teachers for teaching English as a third language in Norway?]. Acta Didactica Norge, 8(2), 1-17. doi:10.5617/adno.1129

Toth, J., \& Paulsrud, B. (2017). Agency and affordance in translanguaging for learning: Case studies from English-medium instruction in Swedish schools. In B. Paulsrud, J. Rosén, B. Straszer, \& $\AA$. Wedin (Eds.), New perspectives on translanguaging and education (pp. 189-207). Bristol, UK: Multilingual Matters. 